\section{DiscoverSys \\ Published by DiscoverSys \\ The 2011 health analysis in Mataram City: application of the Bryant Method}

\author{
Aini Khulaila, ${ }^{1,2 *}$ Made Utama, ${ }^{2}$ Anak Agung Sagung Sawitri ${ }^{3}$
}

\section{ABSTRACT}

The budget for health program of Mataram City is only allocated IDR $39,868,095,387$ or $3.9 \%$ of the total annual city budget. It is lower than minimum $5 \%$ proportion as required by the government regulation. This study involved assessing the priority areas in health according to implicated stakeholders from the health office (head of communicable diseases control, family health, living environments, immunisations and surveillance staff). Data was collected through the months of January-July 2012 through self administered questionnaire using the Bryant Method. Secondary data (census, economic, sociocultural and health records as well as population income levels) was obtained through government records. Data was analysed and interpreted in order to gain insight into perceived priority areas. Cross checking of respondent input was conducted to validate data. Results indicated that the priority health issues are: dengue fever, HIV/AIDS, $T B$, respiratory infections, hypertension, diarrhea and traffic accidents. Obstacles experienced during fieldwork included time restraints from respondents and inconsistencies within secondary data. The absence of the key persons in several discussions and unavailability of written data and reports are the main challenges during investigation. Improving the quality of program data findings and taking the beneficiary of the data source are suggested. Future recommendations include further more qualitative research into the issue, increased collaboration and cooperation between implicated stakeholders as well as more conscientious keeping of public records.

Key words: budget, health problem, Bryant Method

Cite This Article: Khulaila, A., Utama, M., Sawitri, A.A.S. 2013. The 2011 health analysis in Mataram City: application of the Bryant Method. Public Health and Preventive Medicine Archive 1(2): 128-133. D01:10.15562/phpma.v1i2.175

\title{
Analisis kesehatan di Kota Mataram tahun 2011: suatu penerapan Bryant method
}

'Public Health Postgraduate Program Udayana University, ${ }^{2}$ West Nusa Tenggara Health Office, ${ }^{3}$ Department of Community and Preventive Medicine, Faculty of Medicine Udayana University

${ }^{*}$ Correspondence to: Aini Khulaila, Public Health Postgraduate Program Udayana University, West Nusa Tenggara Health Office ainikhulaila@ymail.com
Kata kunci: biaya, masalah kesehatan, Metode Bryant

Kutip artikel ini: Khulaila, A., Utama, M., Sawitri, A.A.S. 2013. Analisis kesehatan di Kota Mataram tahun 2011: suatu penerapan Bryant method. Public Health and Preventive Medicine Archive 1(2): 128-133. D01:10.15562/phpma.v1i2.175 


\section{PENDAHULUAN}

Pembangunan di bidang kesehatan ditujukan untuk meningkatkan derajat kesehatan masyarakat. Derajat kesehatan masyarakat yang meningkat dapat menekan angka kematian bayi dan balita (AKB) dan angka kematian ibu (AKI), sehingga akan meningkatkan Indeks Pembangunan Masyarakat (IPM) sebagai salah satu indikator keberhasilan pembangunan nasional. ${ }^{1}$

Faktor pembiayaan merupakan satu komponen penting yang menentukan keberhasilan. Dinas Kesehatan Kota Mataram telah memperoleh dana upaya kesehatan dari berbagai sumber. Proporsi dana terbesar diperoleh dari APBD Kota Mataram sebesar Rp. 31.811.964.387,- (79,80\%), APBN sebesar Rp. 5.104.415.000,- (12,80\%) dan sumber pemerintah lain (pos bantuan keuangan bagi kesehatan) sebesar Rp. 2.951.720.000 (7,40\%) dengan total dana Rp. 39.868.095.387,-. Jika dibandingkan dengan anggaran total APBD Kota Mataram maka dana upaya kesehatan tersebut hanya sekitar 3,9\%, masih di bawah persentase yang diharapkan. Dalam Undang-undang Kesehatan, proporsi pembiayaan kesehatan diharapkan persentase alokasi anggaran kesehatan sebesar 5\% APBD.

Keterbatasan sumber daya manusia juga menjadi masalah di era desentralisasi. Kewenangan pusat untuk mengatur sumber daya ke daerah lebih terbatas, sehingga di daerah tertentu dijumpai sumber daya tidak optimal untuk melaksanakan pembangunan kesehatan. ${ }^{2}$ Selain itu ketersediaan sarana dan prasarana, sasaran, metode atau cara juga menjadi kendala dalam pelayanan kesehatan. Mempertimbangkan kenyataan tersebut, diperlukan perencanaan upaya pembangunan kesehatan yang akurat agar tujuan pembangunan kesehatan yang seimbang antara kuantitas dan kualitas dapat dicapai.

Analisis dan penentuan prioritas masalah kesehatan yang tepat diperlukan supaya pembangunan kesehatan yang dilakukan memiliki daya ungkit yang besar secara kuantitas dan kualitas terhadap penurunan kesakitan, kecacatan dan kematian. Penyelesaian masalah kesehatan berdasarkan perencanaan wilayah atau evidence based planning, yaitu perencanaan yang dibuat secara terpadu dan benar-benar didasarkan pada besarnya masalah kesehatan, kondisi daerah serta kemampuan sumber daya yang ada dengan program yang mempunyai daya ungkit tinggi dan dapat dilaksanakan dengan efektif dan efisien. ${ }^{3}$ Studi ini bertujuan untuk mengetahui gambaran masalah kesehatan yang merupakan prioritas di Kota Mataram.

\section{METODE}

Analisis masalah kesehatan dilakukan pada Januari-Juli 2012, meliputi analisis situasi wilayah, tinjauan masalah kesehatan, identifikasi dan penetapan atau penentuan masalah prioritas. Rangkaian aktivitas yang dilakukan peneliti adalah: 1) mengumpulkan data sekunder di bidang kesehatan dan bidang terkait lain, 2) analisis dan interpretasi kedalam bentuk ringkasan masalah kesehatan, 3) melakukan diskusi dengan pemegang kebijakan yang relevan, 4) melakukan finalisasi ringkasan masalah, 5) menyebarkan kuesioner yang berisi ringkasan masalah, indikator, sistem skoring kepada pemegang kebijakan terpilih dan 6) melakukan penentuan prioritas. Data sekunder bersumber dari Dinas Kesehatan, BPS dan Bappeda Kota Mataram..$^{4-6}$ Data yang diambil adalah data Januari-Desember 2011, meliputi data geografis, pemerintahan, kependudukan, pendidikan, pekerjaan dan mata pencaharian, keadaan sosial budaya dan kesehatan.

Data dianalisis dan diinterpretasikan kedalam bentuk ringkasan masalah kesehatan dengan mengacu pada indikator-indikator kesehatan serta membandingkan dengan standar pelayanan kesehatan, cakupan, target program kesehatan dan data situasi daerah lain. Selain itu juga dianalisis kejadian dari waktu ke waktu (trend), dampak dan keterkaitan dengan faktor lainnya. Hasil tersebut kemudian dibuat dalam bentuk ringkasan masalah.

Ringkasan masalah kesehatan kemudian didiskusikan dengan dua orang staf dinas kesehatan secara terpisah untuk klarifikasi data dan melakukan identifikasi masalah kesehatan. Setelah masalah kesehatan pokok teridentifikasi, peneliti menuangkan ringkasan masalah pokok beserta sistem skoringnya ke dalam suatu kuesioner. Kuesioner penentuan masalah prioritas disebarkan kepada pemegang kebijakan sebagai tim penilai yaitu staf pimpinan Dinas Kesehatan Kota Mataram sebanyak delapan responden yang terdiri dari: Kepala Bidang Kesehatan Keluarga, Kepala Seksi Pengamatan dan Pencegahan Penyakit, Kepala Seksi Pemberantasan Penyakit dan Bencana, Kepala Seksi Penyehatan Lingkungan dan empat orang pengelola surveilan. Seluruh staf yang ada di Dinas Kesehatan Kota Mataram berjumlah 104 orang. ${ }^{4}$ Dasar pemilihan responden adalah orang yang memiliki pemahaman terhadap permasalahan kesehatan dan berperan dalam pengambilan kebijakan kesehatan di wilayah tersebut.

Dalam menentukan prioritas masalah, metode yang digunakan adalah Metode Bryant $^{7}$ yang dilakukan dalam dua tahap, yaitu pemberian skoring ( $1=$ paling minimal, sampai $5=$ paling 
maksimal) oleh masing-masing tim penilai berdasarkan beberapa kriteria dan dilanjutkan dengan menjumlahkan skor. Nilai yang tertinggi merupakan masalah urutan pertama, urutan selanjutnya sesuai besarnya nilai prioritas masalah kesehatan.

Kriteria dalam penilaian adalah: 1) P (prevalence) atau besar masalah yang menggambarkan jumlah atau kelompok masyarakat yang terkena masalah, makin besar jumlah semakin tinggi skor yang diberikan; 2) S (seriousness) atau keseriusan masalah untuk segera ditanggulangi, misalnya ditinjau dari kegawatan masalah yaitu tingginya angka morbiditas atau mortalitas. Semakin serius masalah semakin tinggi skor yang diberikan; 3) C (community concern) yaitu perhatian atau kepentingan masyarakat dan pemerintah atau instansi terkait terhadap masalah tersebut. Makin tinggi tingkat kepentingannya makin tinggi skor yang diberikan; 4) M (managability) yaitu ketersediaan sumber daya (tenaga, dana, sarana dan metode/cara) yang dibutuhkan untuk mengatasi masalah. Semakin mampu sumber daya yang dibutuhkan, makin tinggi nilai yang diberikan. Penelitian ini menggunakan data publik yang dapat diakses oleh siapa saja sehingga tidak diperlukan kelaikan etik.

\section{HASIL}

Angka Kematian Bayi (AKB) sebesar 4,12 per 1000 lahir hidup dan angka kematian balita (AKABA) sebesar 0,78 per 1000 lahir hidup, dimana $65,79 \%$ kematian terjadi pada bayi $0-28$ hari. Beberapa penyebab utama $\mathrm{AKB}$ adalah berat badan lahir rendah (25\%), asfiksia (25\%) dan ISPA (17,86\%). Keduanya masih di bawah target MDGs (AKB sebesar 23 per 1000 kelahiran hidup $(\mathrm{KH})$ dan balita adalah 32 per $1000 \mathrm{KH}$ ). Angka kematian ibu ditemukan sebesar 104,85/100.000 penduduk, lebih tinggi dari target MDGs (102/100.000) penduduk. Kematian ibu sebagian besar terjadi pada umur 20-35 tahun dengan penyebab kematian perdarahan $20 \%$, infeksi $10 \%$, eklamsia $10 \%$ dan karena sebab lain 60\%.,8

Angka kesakitan di Kota Mataram dihadapkan pada tingginya angka kesakitan penyakit menular disertai meningkatnya penyakit tidak menular. Kesakitan akibat penyakit menular lebih banyak disebabkan oleh penyakit yang berbasis lingkungan dan berpotensi menyebabkan kejadian luar biasa. Beberapa penyakit infeksi yang penting adalah: demam berdarah dengue, ISPA, diare, TB dan HIV/ AIDS.

Demam berdarah dengue diketahui telah menurun di tahun 2011, namun Kota Mataram merupakan daerah endemis dimana setiap bulan selalu terdapat kasus DBD. Selain itu, angka bebas jentik (ABJ) masih rendah yaitu $87,77 \%$ di bawah target nasional 95\%.9 Studi di negara lain menunjukkan DBD merupakan penyebab utama banyaknya pasien anak-anak yang dirawat inap serta kematian anak di banyak negara. Dampak lain adalah beban ekonomi yang signifikan pada masyarakat seperti biaya perawatan di rumah sakit, gangguan signifikan dalam mencari nafkah dan pemerintah juga harus mengeluarkan biaya pengendalian vektor serta seringkali kehilangan kesempatan untuk mendapatkan pemasukan dari sektor pariwisata. ${ }^{10}$

ISPA merupakan penyakit terbanyak pada bayi dan balita di Kota Mataram, yang dapat berlanjut menjadi pneumonia dan dapat menyebabkan kematian. Kasus pneumonia tahun 2011 tercatat sebanyak 4.106 dan merupakan urutan ke-3 dari penyebab kematian bayi yaitu sebesar $17,86 \%$ setelah BBLR dan asfiksia., ${ }^{4,9}$ Kematian akibat pneumonia terkait penyakit penyerta seperti gizi buruk sebesar 2,94\% dan kondisi rumah yang tidak sehat sebesar $39,30 \%$. Hal ini merupakan salah satu faktor yang berperan terhadap perkembangan ISPA menjadi pneumonia. Data menunjukkan kesadaran ibu untuk mengenali kasus ISPA pada anak kemudian membawanya ke fasilitas pengobatan masih rendah, dan kemampuan fasilitas kesehatan yang masih terbatas sehingga kejadian pneumonia kurang dapat dicegah. ${ }^{4}$

Diare merupakan penyakit potensial yang dapat menyebabkan kematian bayi dan balita karena dehidrasi yang disebabkannya. Data tahun 2011 menunjukkan penyakit diare masuk dalam 10 besar penyebab kematian bayi. Jumlah kasus tahun 2011 sebesar 18.091 dan meningkat dari tahun sebelumnya. ${ }^{9}$ Jumlah kasus mungkin lebih besar dari yang terlaporkan karena tidak semua masyarakat memilih pengobatan ke puskesmas. Lebih dari setengah kasus diare terjadi pada balita (54,4\%). Angka ini perlu mendapat perhatian, karena mungkin terkait dengan masalah kurang gizi balita, mengingat angka kurang gizi sebesar 14,54\% dan gizi buruk 2,94\% di Kota Mataram. Penyebab diare berkaitan dengan kondisi sanitasi dasar yang belum sehat, dimana salah satu indikator PHBS terkait diare yang belum mencapai target adalah cuci tangan dengan sabun sebesar $62,91 \%$ dari target $80 \%{ }^{4}$

Tuberkulosis adalah penyakit menular yang cukup banyak dijumpai di Mataram. Di Kota Mataram, ditemukan 258 dari 591 kasus yang diperkirakan menderita TB pada tahun $2011 .{ }^{9}$ Hal ini berarti lebih dari separuh kasus yang belum ditemukan dan potensial menjadi sumber penularan. Angka kesembuhan penderita menurun dari tahun sebelumnya menjadi $87,07 \%$. Pasien 
TB yang dinyatakan tidak sembuh kemungkinan terkait dengan resistensi obat dan diketahui terjadi peningkatan kasus multi drug resistance (MDR). Jika terjadi kekambuhan akan meningkatkan biaya pengobatan. Faktor ekonomi yang rendah menyebabkan kurangnya asupan kalori-protein yang merupakan salah satu stimulan yang mempercepat timbulnya gejala TB pada orang yang sudah terinfeksi.

Secara kumulatif penderita HIV dan AIDS yang dilaporkan di Kota Mataram sampai tahun 2011 mencapai 210 kasus (111 HIV+ dan 99 AIDS), dengan jumlah kematian 51 orang., Walaupun jumlah kasus masih rendah, tetapi kemungkinan penularan dan ledakan kasus dimasa mendatang sangat potensial. Mobilitas penduduk cukup tinggi dimana banyak tenaga kerja Indonesia (TKI) bekerja di luar negeri dalam waktu lama. Kurangnya pengetahuan tentang HIV dan AIDS membuat TKI rentan terinfeksi HIV. ${ }^{11}$ Pengembangan pariwisata daerah dan berdirinya hotel-hotel, cafe dan losmen bisa dijadikan tempat praktek pelacuran terselubung dapat menjadi fokus penularan HIV yang sulit ditanggulangi.

Penyakit hipertensi dijumpai dalam jumlah cukup banyak dimana dalam 2 tahun terakhir selalu masuk dalam 10 besar penyakit. Jumlah kasus tahun 2010 sebanyak 17.680 dan meningkat di tahun 2011 menjadi 22.115 kasus. $^{9}$ Jumlah kasus sebenarnya mungkin lebih tinggi karena data yang diambil berasal dari pasien yang datang ke puskesmas saja, sedangkan data dari klinik swasta, rumah sakit swasta, ataupun praktek dokter swasta belum terlaporkan. Hipertensi adalah penyakit kronis tanpa gejala sehingga membuat pasien tidak segera memeriksakan diri ke fasilitas layanan kesehatan. Adanya kecenderungan perilaku masyarakat di Indonesia, termasuk juga di Kota Mataram, masih berorientasi pada keluhan sehingga apabila tanpa keluhan maka penderita tidak memeriksakan diri ke layanan kesehatan. Jika seluruh kasus tercatat, kemungkinan besar hipertensi menempati urutan jumlah kasus lebih atas dibandingkan penyakit lainnya. Banyak faktor risiko hipertensi terkait perilaku atau gaya hidup. Di Kota Mataram, proporsi perilaku merokok sangat tinggi $(57,46 \%)$ dan angka kelebihan gizi sebanyak $0,88 \%$.,9 Keduanya juga merupakan faktor risiko hipertensi dimasa datang.

Dampak penyakit hipertensi cukup berat karena merupakan penyakit seumur hidup dan diperlukan upaya untuk menjaga kestabilan tekanan darah, yang membutuhkan biaya tambahan yang tidak sedikit seumur hidupnya. Hipertensi sering merupakan faktor risiko timbulnya penyakit jantung. ${ }^{11}$ Kondisi ini menjadikan penyebab kematian yang tinggi dan disability-adjusted life years (DALYs) yang tinggi, dan berdampak pada biaya perawatan yang tinggi seumur hidup..$^{13}$

Jumlah kecelakaan lalu lintas di Kota Mataram cenderung meningkat. Data Kepolisian Resort Kota Mataram tahun 2011 menyebutkan terjadi 341 kecelakaan dengan jumlah kematian 82 orang. Persentase kematian sebesar (24,0\%) dan perkiraan kerugian mencapai Rp. 639.450.000,- Meningkatnya jumlah kendaraan utamanya sepeda motor, kurangnya kesadaran pengendara dalam memakai helm/sabuk pengaman standar, upaya penegakan hukum yang kurang memadai jika ada pelanggaran, keterbatasan fasilitas (jalan, penerangan dan lampu lalu lintas), serta faktor individu seperti pemakaian alkohol, helm, telepon seluler, merupakan faktor risiko terjadinya kecelakaan lalulintas. Dampak yang paling berat dari kecelakaan adalah kematian dan kecacatan seumur hidup. Utamanya dampak kecacatan yang bisa mengganggu produktivitas seseorang dan akhirnya berdampak menjadi beban bagi keluarga dan masyarakat. Upaya pencegahan yang dapat dilakukan adalah dengan menggunakan helm untuk pengendara kendaraan motor atau sabuk pengaman bagi pengendara kendaraan mobil, namun pencegahan ini hanya untuk mengurangi dampak berat jika terjadi kecelakaan. Anjuran kepolisian bagi pengendara motor untuk menggunakan helm standar, jaket warna terang, menyalakan lampu pada siang hari juga merupakan bagian dari upaya pencegahan. ${ }^{14}$

Berdasarkan hasil diskusi masalah kesehatan, staf dinas kesehatan menyatakan penyakit-penyakit infeksi menular seperti DBD, ISPA, diare, TB paru, HIV-AIDS tetap menjadi prioritas masalah yang harus segera diselesaikan. Status gizi yang merupakan salah satu faktor risiko meningkatnya penyakit menular seperti diare, ISPA, TB paru memang masih menjadi masalah di Kota Mataram, tetapi karena kasusnya cenderung menurun dan sudah lebih rendah dari target MDGs, bukan lagi menjadi prioritas masalah yang harus segera diintervensi. Walaupun demikian, kegiatan penanggulangan saat ini harus tetap dilakukan agar kasus tidak kembali meningkat. Penyakit menular lainnya seperti malaria dan demam chikungunya, dinyatakan sudah dapat ditekan dan cenderung menurun. Malaria tidak lagi endemis dan chikungunya amat jarang menimbulkan kematian sehingga penyakit tersebut menjadi masalah yang kurang prioritas. Masalah-masalah lain seperti perilaku hidup masyarakat, pelayanan kesehatan dan sumber daya kesehatan, tidak dianggap masalah yang harus segera ditangani. Kecenderungan peningkatan kasus penyakit tidak menular yang selama ini belum pernah diangkat sebagai prioritas masalah dinyatakan karena keterbatasan data dan dana. Responden sangat 
Tabel 1 Hasil penilaian masalah oleh pemegang kebijakan dan pelaksana program kesehatan Dinas Kesehatan Kota Mataram tahun 2012

\begin{tabular}{|c|c|c|c|c|c|c|c|}
\hline Kriteria/Indikator & Diare & ISPA & HIV & DBD & TBC & Hipertensi & $\begin{array}{c}\text { Kecelakaan } \\
\text { lalu lintas }\end{array}$ \\
\hline Besar/luasnya masalah & 24 & 26 & 30 & 35 & 28 & 30 & 29 \\
\hline Angka kesakitan & 26 & 27 & 28 & 34 & 28 & 27 & 26 \\
\hline Angka kematian & 15 & 18 & 26 & 23 & 19 & 20 & 22 \\
\hline Kecenderungan & 26 & 27 & 31 & 33 & 26 & 29 & 25 \\
\hline Dukungan pemerintah/masyarakat & 28 & 25 & 31 & 29 & 29 & 23 & 23 \\
\hline Ketersediaan tenaga & 27 & 27 & 27 & 29 & 28 & 25 & 25 \\
\hline Ketersediaan dana & 24 & 25 & 25 & 28 & 27 & 22 & 20 \\
\hline Ketersediaan metode/cara & 31 & 31 & 31 & 33 & 32 & 30 & 30 \\
\hline Ketersediaan sarana & 29 & 29 & 29 & 30 & 30 & 27 & 23 \\
\hline Jumlah & 230 & 235 & 258 & 274 & 247 & 233 & 223 \\
\hline Prioritas & 6 & 4 & 2 & 1 & 3 & 5 & 7 \\
\hline
\end{tabular}

menekankan perlunya mengidentifikasi masalah tersebut sejak dini karena kasus yang cukup banyak dan cenderung meningkat untuk menjaga agar di masa datang tidak menjadi beban tambahan dalam masalah kesehatan.

Hasil diskusi menunjukkan masalah kesehatan yang teridentifikasi adalah DBD dengan alasan endemis, berpotensi dan sering menjadi KLB dan meresahkan masyarakat. Masalah kedua adalah ISPA karena merupakan penyakit terbanyak di puskesmas. Masalah ke tiga adalah diare karena kasus meningkat dan lebih banyak menyerang balita. Urutan selanjutnya TB karena case detection rate (CDR) belum mencapai target dan berpotensi banyak terjadi multi drugs resistant (MDR), disusul HIV dan AIDS karena angka kematian dan dampak sosial ekonomi yang tinggi. Penyakit hipertensi karena terus meningkat dan perlu penanganan dini untuk antisipasi jangka panjang dan kecelakaan lalu lintas karena terus meningkat dan angka kematian cukup tinggi.

Masalah kesehatan yang teridentifikasi kemudian diberikan kepada responden pemegang kebijakan dan pelaksana program kesehatan untuk dinilai dan dilakukan skoring guna menetapkan skala prioritasnya. Peneliti menjumlahkan skor semua penilai dengan hasil seperti pada Tabel 1, dimana urutan prioritas masalah kesehatan di Kota Mataram yang harus segera ditangani adalah DBD, selanjutnya secara berurutan adalah IMS/ HIV/AIDS, TB paru, ISPA, hipertensi, diare dan kecelakaan lalu lintas.

\section{DISKUSI}

Pada penentuan prioritas masalah, dari 10 responden, dua tidak bisa mengumpulkan kuesioner karena sesaat setelah menerima kuesioner yang bersangkutan mengikuti perjalanan dinas yang cukup lama. Responden yang tersisa, sebagian besar (80\%) berasal dari Bidang P3PPL, sehingga dalam penentuan identifikasi masalah dan penentuan prioritas masalah cenderung subyektif memilih prioritas masalah sesuai dengan bidangnya. Hal tersebut tercermin dalam prioritas masalah yang seluruhnya adalah kegiatan di P3PPL. Pertimbangan masalah kesehatan di bidang lain misalnya kesehatan keluarga atau ketenagaan sangat minimal. Beberapa indikator program menunjukkan hal dalam Tabel 1 tersebut masih merupakan masalah kesehatan yang harus ditanggulangi segera.

Hasil analisis masalah kesehatan prioritas Kota Mataram tahun 2011 ini tidak jauh berbeda dengan hasil analisis masalah kesehatan di tahun sebelumnya (2010) dengan menggunakan metode PAHO (Pan American Health Organization). ${ }^{15}$ Penyakit DBD menempati urutan pertama penyakit yang harus segera ditangani. Penyakit DBD tetap merupakan masalah prioritas karena DBD bersifat endemis dan sangat mudah menyebabkan KLB (kejadian luar biasa). Hasil analisis kesehatan tahun 2010 telah ditindaklanjuti pemerintah Kota Mataram dengan alokasi dana cukup besar. Penurunan kasus DBD terjadi dari 1.014 kasus dengan 3 kematian (CFR 0,30\%) di tahun 2010 menjadi 170 kasus di tahun 2011 tanpa kasus kematian. Urutan selanjutnya pada analisis di tahun 2010 adalah chikungunya, gizi buruk, ISPA, diare, HIV/AIDS dan TB.

Pada pemberian skor, nilai yang lebih tinggi cenderung diberikan pada permasalahan dimana telah tersedia sumber dana yang memadai. Kegiatan yang diprioritaskan oleh penilai berdasarkan dana yang tersedia, dimana semakin besar dana semakin tinggi prioritasnya seperti terlihat pada hasil skoring yaitu prioritas masalah 
ada pada DBD, HIV/AIDS dan TB Paru. Ketiga penyakit ini mempunyai jumlah dana yang cukup banyak dibanding penyakit lain, karena selain dari dana APBD, sumber dana lain yaitu Anggaran Belanja Tambahan (ABT) dan bantuan luar negeri terbilang cukup memadai. Hal ini bisa juga terjadi karena ketersediaan dana menyebabkan data yang tersedia menjadi lebih lengkap dan akurat, demikian pula potensi upaya penanggulangan menjadi lebih terbuka. Sementara untuk penyakit dengan pendanaan yang sedikit seperti ISPA, data yang tersedia hanya untuk keperluan pencatatan dan pelaporan saja.

Sumber data yang sebagian besar berasal dari dinas kesehatan juga mempengaruhi kualitas penentuan masalah kesehatan. Penggabungan data yang berasal dari berbagai sumber misalnya dari dinas kesehatan, rumah sakit pemerintah ataupun swasta, klinik-klinik swasta tentunya akan menggambarkan permasalahan kesehatan yang berbeda, baik itu prevalensi maupun kecenderungannya.

Beberapa kelemahan dalam melakukan analisis masalah kesehatan diantaranya adalah pada pemilihan responden, dalam hal ini belum dapat melibatkan semua pemegang posisi penting yang ada di jajaran Dinas Kesehatan Kota Mataram (kadin, kasubdin, kaseksi, ka TU, kepala puskesmas). Keterbatasan waktu para penentu kebijakan menyebabkan pertemuan diskusi dengan semua penentu kebijakan tidak mungkin dilakukan. Diskusi kecil hanya bisa dilakukan peneliti dengan 2 orang staf dinas secara terpisah dan menghasilkan pembahasan yang terbatas.

Masih terlihat adanya ego dimasing-masing program, ketika menganalisis satu masalah program selalu berjalan sendiri-sendiri, belum mengkaji permasalahan secara bersama-sama, walaupun saling berkaitan, misalnya penyakit TB paru, tidak pernah dikaitkan dengan kondisi lingkungan, seharusnya kajian permasalahan dapat dilakukan lebih komprehensif dan mendalam dengan melakukannya secara bersama-sama baik itu bagian perencanaan, keuangan dan subdinas sehingga menghasilkan program kesehatan yang efektif dan efisien.

\section{SIMPULAN}

Masalah kesehatan masyarakat Kota Mataram lebih banyak didasarkan pada data puskesmas/dinas kesehatan, sebagian dari data statistik dan data hasil-hasil survei (PHBS). Urutan prioritas masalah di Kota Mataram tahun 2011 adalah DBD, IMS/ HIV-AIDS, TB paru, ISPA, hipertensi, diare dan kecelakaan lalu lintas.
Dalam perencanaan jangka panjang di masa mendatang, agar seluruh pemegang posisi penting (kadin, kasubdin, kaseksi, ka TU, kepala puskesmas) dapat melakukan pengkajian hasil analisis masalah secara bersama-sama dengan periode waktu yang memadai sehingga perencanaan dapat dilakukan lebih baik. Melakukan upaya peningkatan kualitas data program, memanfaatkan semua sumber data yang ada sehingga data yang tersedia dapat menggambarkan situasi kesehatan masyarakat yang sebenarnya.

\section{UCAPAN TERIMA KASIH}

Ucapan terima kasih disampaikan kepada Kepala Dinas Kesehatan Kota Mataram, Kepala Bidang P3PPL Dinas Kesehatan Kota Mataram, Kepala Bidang Kesehatan Keluarga Dinas Kesehatan Kota Mataram, serta semua rekan yang membantu terlaksananya penelitian ini.

\section{DAFTAR PUSTAKA}

1. Kementrian Kesehatan Republik Indonesia. Indeks Pembangunan Kesehatan Masyarakat; 2010.

2. Departemen Kesehatan Republik Indonesia. Profil Kesehatan Indonesia. Jakarta; 2008.

3. Purwoko W. Analisis Masalah Kesehatan Kota Mataram. Mataram; 2010.

4. Dinas Kesehatan Kota Mataram. Profil Kesehatan Kota Mataram. Mataram; 2011.

5. Badan Pusat Statistik Kota Matara. Mataram Dalam Angka 2010. Mataram; 2010.

6. Bappeda Kota Mataram. Tujuh Belas Tahun Kota Mataram; 2011.

7. Universitas Jenderal Soedirman Fakultas Kedokteran dan Ilmu-Ilmu Kesehatan. Buku Pedoman Praktek Belajar Lapangan. Jakarta; 2010.

8. Dinas Kesehatan Kota Mataram. Rekapitulasi Laporan Hasil Kegiatan Bidang Pembinaan Kesehatan Keluarga Dinas Kesehatan Kota Mataram. Mataram; 2011.

9. Dinas Kesehatan Kota Mataram. Rekapitulasi Laporan Hasil Kegiatan Bidang P3-PPL Dinas Kesehatan Kota Mataram. Mataram; 2011.

10. Adi PD. Analisis Masalah Kesehatan di Provinsi Bali. 2010.

11. BNP2TKI. Kebijakan dan Strategi Pencegahan dan Penanggulangan HIV/AIDS Dalam Penempatan dan Perlindungan TKI Keluar Negeri. 2007.

12. Basha A. Hipertensi: faktor risiko dan penatalaksanaannya. 2008.

13. Rodgers A, Gaziano T, Vos T. The Growing Burden of Risk from High Blood Pressure, Cholesterol, and Bodyweight in Disease Control Priorities in Developing Countries. 2005.

14. Pusdaldukkes. Kecelakaan Lalu Lintas dan Masalah Perkotaan. 2007.

15. WHO. PAHO Basic Health Indicator Data Based. US; 2005.

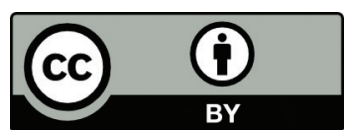

This work is licensed under a Creative Commons Attribution 